\title{
Effects of fractionated colostrum replacer and vitamins $A, D$, and $E$ on haptoglobin and clinical health in neonatal Holstein calves challenged with Mycobacterium avium ssp. paratuberculosis
}

\author{
L. A. Krueger, ${ }^{\star} \dagger$ T. A. Reinhardt, $\dagger$ D. C. Beitz, ${ }^{*}$ R. L. Stuart, $\ddagger$ and J. R. Stabel ${ }^{1}$ \\ *Department of Animal Science, lowa State University, Ames 50011 \\ †USDA-Agricultural Research Service, National Animal Disease Center, Ames, IA 50010 \\ ¥Stuart Products Inc., Bedford, TX 76022
}

\section{ABSTRACT}

Thirty Holstein calves were obtained from 2 dairy farms in central Iowa at birth and randomly assigned to 1 of 6 treatment groups: (1) colostrum deprived (CD), no vitamins; (2) colostrum replacer (CR), no vitamins; (3) $\mathrm{CR}$, vitamin $\mathrm{A}$; (4) $\mathrm{CR}$, vitamin $\mathrm{D}_{3}$; (5) $\mathrm{CR}$, vitamin $\mathrm{E}$; and (6) $\mathrm{CR}$, vitamins $\mathrm{A}, \mathrm{D}_{3}, \mathrm{E}$, with 5 calves per treatment in a 14-d study. Calves were fed pasteurized whole milk (CD) or fractionated colostrum replacer (CR) at birth (d 0) and injected with vitamins according to treatment group. From d 1 through d 14 of the study, all calves were fed pasteurized whole milk (PWM) supplemented with vitamins as assigned. All calves were inoculated with Mycobacterium avium ssp. paratuberculosis on $\mathrm{d} 1$ and 3 of age. Calves fed CR acquired $\operatorname{IgG}_{1}$ and haptoglobin in serum within $24 \mathrm{~h}$ of birth, whereas CD calves did not. The CR-fed calves were 2.5 times less likely to develop scours, and CR calves supplemented with vitamins $\mathrm{D}_{3}$ and $\mathrm{E}$ also demonstrated a decreased incidence of scours. Serum vitamin levels of $\mathrm{A}, \mathrm{D}$, and $\mathrm{E}$ increased within treatment group by $\mathrm{d} 7$ and 14 of the study. Interestingly, synergistic effects of supplemental vitamins $\mathrm{A}, \mathrm{D}_{3}$, and $\mathrm{E}$ on serum 25-(OH)-vitamin D were observed at d 7, resulting in higher levels than in calves administered vitamin $\mathrm{D}$ only. Further, vitamin $\mathrm{D}_{3}$ deficiency was observed in $\mathrm{CD}$ and $\mathrm{CR}$ calves fed a basal diet of pasteurized whole milk and no supplemental vitamins. Colonization of tissues with Mycobacterium avium ssp. paratuberculosis was negligible and was not affected by colostrum feeding or vitamin supplementation. Results demonstrated passive transfer of haptoglobin to neonatal calves, and potential health benefits of supplemental vitamins $D_{3}$ and $\mathrm{E}$ to calves fed pasteurized whole milk.

Key words: dairy calf, colostrum, vitamin, acute phase protein

Received September 14, 2015.

Accepted December 6, 2015.

${ }^{1}$ Corresponding author: judy.stabel@ars.usda.gov

\section{INTRODUCTION}

Pasteurized whole milk (PWM) is a common component in calf diets on commercial dairy farms in the United States, as producers seek to capture losses from waste milk. Recent literature, however, has suggested that PWM alone does not meet the vitamin $\mathrm{A}, \mathrm{D}_{3}$, and $\mathrm{E}$ nutritional requirements of young calves and that these requirements are increased by increased growth rates and immune challenge (Krueger et al., 2014; Nonnecke et al., 2014). Suggested mechanisms by which vitamin $\mathrm{A}$ and $\mathrm{D}_{3}$ metabolites affect growth and immunity include the targeting of nuclear receptors to affect cell differentiation, tissue development, and immune cell signaling (Hall et al., 2011; Nelson et al., 2012; Rhinn and Dollé, 2012), whereas vitamin E is an antioxidant that protects cell membrane unsaturated fatty acids from oxidative processes such as respiration and inflammation (Traber and Atkinson, 2007). Pasteurized whole milk contains approximately 38.4 and 1.8 IU/L of vitamins $\mathrm{D}_{3}$ and $\mathrm{E}$, respectively, falling short of recommended daily allowances (582 and $26.5 \mathrm{IU}$, respectively) for neonatal calves (NRC, 2001; Krueger et al., 2014). Pasteurized whole milk may satisfy the nutritional requirement for vitamin A in healthy, milkfed calves, but animals experiencing inflammation have exhibited decreased serum retinol and retinol binding protein (Rosales et al., 1996; Krueger et al., 2014). Thus, supplemental vitamins $\mathrm{A}, \mathrm{D}_{3}$, and $\mathrm{E}$ may benefit the neonatal calf. Commercial milk replacers often include vitamins in concentrations above those recommended by NRC (2001) as a recent technical bulletin recommended daily fortification of PWM with 20,000, 7,500, and $100 \mathrm{IU}$ of vitamins $\mathrm{A}, \mathrm{D}_{3}$, and $\mathrm{E}$, respectively, for neonatal calf diets (Wood, 2013).

Although the health of neonatal calves may be affected by vitamin deficiencies, it is clear that colostrum intake plays a significant role in immune maturation and decreased morbidity. At birth, newborn calves possess cells and other components that compose the innate and adaptive arms of immunity, but lack endog- 
enous antibody and are highly susceptible to infection at epithelial barriers within the lungs and intestine. Feeding colostrum to calves within the first $24 \mathrm{~h}$ of life is accepted widely as an effective means of delivering passive protection in a dose-dependent manner (Robison et al., 1988). Maternal colostrum contains $\operatorname{IgG}_{1}$ antibodies, leukocytes, complement, and cytokines that confer passive immunity (Chase et al., 2008). Because colostral leukocytes are degraded during the pasteurization and freezing processes that are recommended for commercial handling of colostrum, immune stimulatory benefits are primarily attributed to compounds in the whey fraction. Fractionated colostrum replacer, used in this study, is concentrated colostral whey that contains $\operatorname{IgG}_{1}$ and many other nonnutritive, bioactive compounds such as IGF, lactoferrin, lysozyme, and lactoperoxidase (Tripathi and Vashishtha, 2006). As passively transferred immunity wanes during early life, acquired immunity is essential for survival, but is potentially impaired by fat-soluble vitamin deficiencies in calves fed only PWM.

Acquired, cell-mediated $\mathrm{T}_{\mathrm{H}} 1$ responses, marked by pro-inflammatory cytokines, are an important part of controlling subclinical infections of Mycobacterium avium ssp. paratuberculosis (MAP) in adult bovine animals (Stabel, 2010). Infection rates of this pathogen are greatest during the neonatal stage when fecal-oral transmission risk is high upon exposure to infected dams in the maternity pen. Additionally, transmission to the neonate can occur via colostrum and milk of infected dams (Stabel et al., 2014). Although infection as a neonate is not known to cause acute inflammatory distress, the organism can survive and replicate in the host during a long subclinical latency before overt immune responses become evident (Stabel, 2010). Complications due to colostrum deprivation, vitamin deficiencies, or both may exacerbate the infectivity of young neonates with MAP.

The present study was designed to address the effect of colostrum deprivation and feeding pasteurized whole milk as a basal diet to neonatal calves to determine effects on general health and inflammation. Additionally, supplemental vitamins were provided to provoke calfhood immunity and attenuate inflammatory responses. We sought to use vitamin supplementation standards consistent with commercial standards (Wood, 2013; Krueger et al., 2014), which are in excess of NRC (2001) recommendations. A neonatal MAP infection model was overlaid in the study design to ascertain specific effects of colostrum feeding and vitamin supplementation on uptake of MAP in the first $2 \mathrm{wk}$ of life, a critical period of pathogen susceptibility for the neonatal calf. This study was thus conducted to assess whether colostrum and supplemental vitamins $\mathrm{A}, \mathrm{D}_{3}$, and $\mathrm{E}$ affect the inflammatory status of calves fed PWM by measuring serum acute phase proteins haptoglobin $(\mathbf{H p})$ and serum amyloid A (SAA), and whether these dietary treatments subsequently alter the MAP infection status of bovine neonates.

\section{MATERIALS AND METHODS}

\section{Study Design}

Treatments. Thirty Holstein calves were obtained from 2 dairy farms in central Iowa at birth and randomly assigned to 1 of 6 treatment groups: (1) colostrum deprived (CD), no vitamins; (2) colostrum replacer (CR), no vitamins; (3) colostrum replacer, vitamin A (CR-A); (4) colostrum replacer, vitamin $\mathrm{D}_{3}$ (CR-D); (5) colostrum replacer, vitamin E (CR-E); (6) colostrum replacer, vitamins $\mathrm{A}, \mathrm{D}_{3}$, and $\mathrm{E}$ (CR-ADE), with 5 calves per treatment in a 14-d study, as depicted in Figures 1A and 1B. All calves received a first feeding of colostrum replacer or PWM within $4 \mathrm{~h}$ of birth; the $\mathrm{CD}$ calves were fed $1.9 \mathrm{~L}$ of $\mathrm{PWM}\left(40^{\circ} \mathrm{C}\right.$, Iowa State University Dairy Farm, Ames) as a control, whereas calves in the remaining 5 treatment groups received $375 \mathrm{~g}$ of fractionated colostrum replacer (Milk Products, Chilton, WI) reconstituted in $1.9 \mathrm{~L}$ of water at approximately $40^{\circ} \mathrm{C}$. The colostrum replacer contained $150 \mathrm{~g}$ of bovine globulin protein concentrated from colostral whey and was essentially considered devoid of all fat-soluble vitamins $\mathrm{A}, \mathrm{D}_{3}$, and E. Calves received their respective vitamin treatments at the time of first feeding and throughout the study. Calves in vitamin treatment groups were administered 3-mL injections subcutaneously at birth to deliver 150,000 IU of retinyl palmitate (CR-A), 150,000 IU of cholecalciferol (CR$\mathrm{D})$, and 1,500 IU of D- $\alpha$-tocopherol (CR-E). Thereafter (d 1-14 of study), calves assigned to vitamin treatment groups were orally administered 25,000, 5,000, and 500 IU of the respective compounds daily in their dietary milk. The CR-ADE calves received an injection or oral solution containing vitamins $\mathrm{A}, \mathrm{D}_{3}$, and $\mathrm{E}$ in the concentrations described above. Calves in the CD and CR control groups were injected with $3 \mathrm{~mL}$ of placebo carrier solution at birth (proprietary formulation, Stuart Products Inc., Bedford, TX).

Housing and Feeding. All calves were transported within $12 \mathrm{~h}$ of birth to the National Animal Disease Center, (NADC, Ames, IA). All animal procedures performed were approved by the Animal Care and Use Committee (NADC). Calves were housed indoors in individual pens elevated from a concrete floor. Ambient temperature was held at approximately $20^{\circ} \mathrm{C}$. Upon arrival, calves were placed on a twice-daily feeding schedule with 12-h intervals with approximate feeding times 
at 0600 and $1800 \mathrm{~h}$. At each feeding, calves were fed 2.7 L of PWM that was transported daily from the Iowa State University Dairy Farm, Ames. A 50-mL sample of dietary milk from each feeding was retained and stored at $-20^{\circ} \mathrm{C}$ for later analyses. All calves were offered milk via bottle and nipple, but refusals of greater than $0.1 \mathrm{~L}$ were administered to the calf via esophageal tube. Calves received $1 \mathrm{~mL}$ of oral vitamin solution via dietary milk at each evening feeding, according to treatment group. The first morning feeding in the study location marked d 1 of the study.

MAP Infection. All calves were inoculated twice via dietary milk with $10^{8} \mathrm{cfu}$ per dose of MAP, strain 167 (clinical isolate, NADC, Ames, IA) in PWM, as

A

\section{0 calves collected at birth}
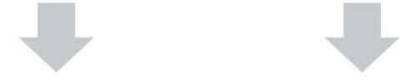

$$
\mathrm{CD}(\mathrm{n}=5)
$$

$\mathrm{CR}(\mathrm{n}=25)$

\begin{tabular}{l|c|c|c|c}
$\begin{array}{l}\text { CR } \\
(\mathrm{n}=5)\end{array}$ & $\begin{array}{c}\text { CR-A } \\
(\mathrm{n}=5)\end{array}$ & $\begin{array}{c}\text { CR-D } \\
(\mathrm{n}=5)\end{array}$ & $\begin{array}{c}\text { CR-E } \\
(\mathrm{n}=5)\end{array}$ & $\begin{array}{c}\text { CR-ADE } \\
(\mathrm{n}=5)\end{array}$
\end{tabular}

B

d 0 (within $4 \mathrm{~h}$ )

Feed PWM (CD) or colostrum replacer (CR) Injection with vitamin or placebo
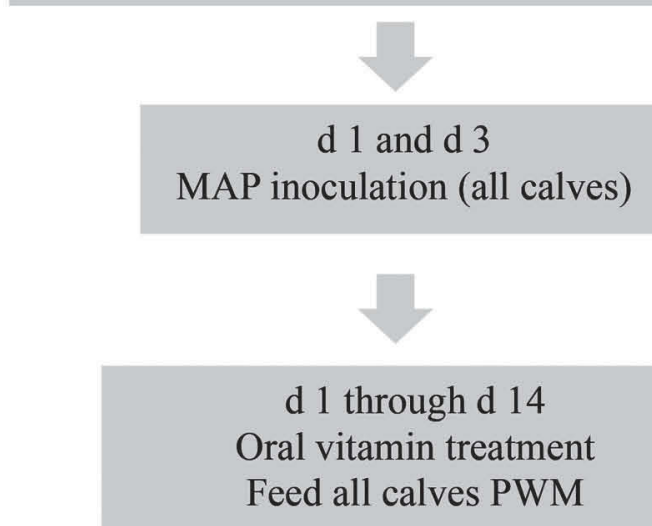

d 14: Necropsy

Figure 1. (A) Experimental design, with 5 calves per treatment group. CD, colostrum deprived; CR, colostrum replete; A, supplemented with vitamin $\mathrm{A} ; \mathrm{D}$, supplemented with vitamin $\mathrm{D}_{3}$; $\mathrm{E}$, supplemented with vitamin $\mathrm{E}$. (B) Timeline of experimental procedures. PWM $=$ pasteurized whole milk; MAP = Mycobacterium avium ssp. paratuberculosis. 
previously described (Stabel et al., 2013) during the morning feedings of $d 1$ and 3 .

\section{Health Scoring and Sample Collection}

Health Scoring. Calves were evaluated by investigators for 5 criteria that indicated general health status, including rectal temperature, cough, nasal discharge, fecal consistency, and attitude upon arrival and at each feeding thereafter. The health score matrix was based upon an unpublished, veterinary clinical health score system for young calves. Prior to initiation of the study, all personnel involved in feeding and care of the calves were trained in the scoring matrix and provided with photographic representations of each criteria at each scoring level. Fecal consistency and attitude scores were assigned on a scale of 0 to 3 . For fecal consistency, a score of 0 indicated a normal and solid consistency, a score of 1 was equivalent to semi-formed and pasty feces, a score of 2 was equivalent to loose feces, and a score of 3 was equivalent to watery feces and severe, debilitating scours. For attitude, a score of 0 was used to record an alert calf free of ocular discharge, a score of 1 was used to record minor ocular discharge or an ear flick, a score of 2 was used to record moderate ocular discharge or unilateral ear droop, and a score of 3 was used to record heavy ocular discharge, bilateral ear droop, or general unresponsiveness.

Fecal Pathogen Diagnosis. Approximately $5 \mathrm{~g}$ of feces was collected from each calf daily. Feces collected at d 13 from all CD calves and 2 calves from each of the other CR treatments were sent to a commercial laboratory and were subject to a bovine enteric PCR panel (Iowa State University Veterinary Diagnostic Laboratory) to detect the presence (positive or negative) of potential, uncontrolled pathogens, including bovine Coronavirus, Rotavirus group A, Escherichia coli (K99+), Cryptosporidium parvum, and Salmonella spp. that might contribute to scours and morbidity.

Blood Collection. Whole blood was collected via jugular venipuncture from all animals on d 0 within 4 $\mathrm{h}$ of birth and before vitamin injection. Blood was collected from all animals again on d 1 at 12 to $24 \mathrm{~h}$ postpartum, $\mathrm{d} 7$, and $\mathrm{d} 14$ before morning milk feeding and after a 12-h fast. At each time point, $20 \mathrm{~mL}$ of blood was collected into vacutainer tubes (Becton, Dickinson and Co., Franklin Lakes, NJ) and serum was harvested and stored at $-20^{\circ} \mathrm{C}$ until analyses were performed.

Necropsy. Calves were fed according to schedule for $13 \mathrm{~d} \pm 1$ and were euthanized on $\mathrm{d} 14 \pm 1$ for collection of intestinal tissues, which included duodenum, proximal jejunum, mid-jejunum, distal jejunum, ileum, ileo-cecal valve, spiral colon, transverse colon, descend- ing colon, and lymph nodes of each region, as well as cecum, liver, spleen, and the jejunal mesenteric lymph node chain. Tissues were rinsed with $0.15 \mathrm{MPBS}$, and cross-sections were frozen at $-80^{\circ} \mathrm{C}$.

\section{Sample Analyses}

Ig $G_{1}$ and Acute Phase Proteins. Immunoglobulin $\mathrm{G}_{1}$ in sera was quantified by capture ELISA, as described by Nonnecke et al. (2012). Antibodies (\#A10-116A, \#A10-116P) and reference sera (RS10-103) for the assay were purchased from Bethyl Laboratories Inc. (Montgomery, TX), and colorimetric reagents (\#52-00-00, \#50-85-04) were purchased from Kirkegaard and Perry Laboratories Inc. (Gaithersburg, MD). Sera were diluted 1:60,000 to achieve absorbance values within range of the standard curve. Haptoglobin was quantified by using a bovine-specific Hp ELISA (Immunology Consultants Laboratory Inc., Newberg, OR) according to manufacturer's instructions. Serum samples were diluted 1:50 in $1 \times$ diluent according to the manufacturer's instructions. Samples that resulted in absorbance values $(450 \mathrm{~nm}$ for $0.1 \mathrm{~s}$ on a Victor X3 2030 multilabel reader, Perkin Elmer, Waltham, MA) that fell outside of the standard curve were diluted 1:5,000 or 1:10,000 to achieve absorbance values within range. Serum amyloid A was quantified by using the Phase Range Multispecies SAA ELISA kit (Tridelta Development Ltd., Maynooth, Co. Kildare, Ireland) according to the manufacturer's instructions. Sera were diluted 1:5,000 to achieve absorbance values within range of the standard curve. Absorbance was determined for each sample as described for serum Hp. Haptoglobin, SAA, and $\mathrm{IgG}_{1}$ were quantified in colostrum replacer by using ELISA procedures as already described. For $\operatorname{IgG}_{1}$ quantification, colostrum replacer was reconstituted as fed, and then dilutions were prepared at 1:25,000, 1:100,000, 1:200,000, 1:400,000, $1: 800,000$, and 1:1,600,000. For Hp and SAA quantification, dilutions were prepared at 1:500, 1:1,000, 1:2,000, and 1:4,000.

Vitamin Analyses. Retinol and $\alpha$-tocopherol were quantified in serum and dietary milk by reverse-phase (RP) HPLC after extraction with hexane as described by Goff et al. (2002). Retinyl palmitate was additionally quantified in serum of CR, CR-A, and CR-ADE calves only, using procedures described by Stahr (1991). Total 25-(OH)-vitamin D equivalents were quantified by RIA after extraction of serum with acetonitrile. Serum $(50 \mu \mathrm{L})$ was added to $500 \mu \mathrm{L}$ of acetonitrile and mixed carefully. Then, $25 \mu \mathrm{L}$ of the extracted sample was combined with an equal volume of radioiodinated $25-(\mathrm{OH})$-vitamin D (Diasorin; 10,000 $\mathrm{cpm}$ in $25-\mu \mathrm{L}$ 
ethanol with $0.01 M$ sodium phosphate). The samples were then centrifuged at $2,000 \times g$ for $10 \mathrm{~min}$ at room temperature, and the pellet was discarded. The RIA then was conducted as described by Hollis et al. (1993). Retinol and $\alpha$-tocopherol were quantified in 6 milk samples representative of the entire study period by using procedures already described.

Tissue Culture. Tissues obtained at necropsy were homogenized in $0.9 \%$ hexadecylpyradinium chloride solution with a gentleMACS Octo Dissociator, using M tubes (Miltenyl Biotec, San Diego, CA). Following overnight incubation, homogenates were pelleted by centrifugation at $900 \times g$ for $30 \mathrm{~min}$ at room temperature and re-suspended in antibiotic medium containing $100 \mu \mathrm{g} / \mathrm{mL}$ of nalidixic acid, $100 \mu \mathrm{g} / \mathrm{mL}$ of vancomycin, and $50 \mu \mathrm{g} / \mathrm{mL}$ of amphotericin B (Sigma). Samples were incubated overnight followed by inoculation of a $200-\mu \mathrm{L}$ sample onto each of 4 slants of Herrold's egg yolk medium (Becton Dickinson, Franklin Lakes, NJ). Slants were incubated at $39^{\circ} \mathrm{C}$ for at least $12 \mathrm{wk}$, and colony counts of viable MAP were recorded and averaged for the 4 slants. Confirmation of MAP colonies was performed by picking colonies off the Herrold's egg yolk medium slants, boiling in ultra-pure water distilled water (Life Technologies) to release the DNA, followed by IS900 PCR as described by Leite et al. (2013).

\section{Statistical Analyses}

Vitamin concentrations in serum were analyzed by repeated measures ANOVA by using mixed procedures of SAS (version 9.3, SAS Institute Inc., Cary, NC). Calf served as the experimental unit. The model included fixed effects of treatment and sample day with calf included as a random effect. Contrast statements were used to separate least squares means on the basis of colostrum and vitamin supplementation.

The $\operatorname{IgG}_{1}$ in serum at $\mathrm{d} 1$ was analyzed by using contrast statements in mixed procedures of SAS to separate least squares means on the basis of colostrum supplementation only. Serum acute phase proteins were analyzed similarly within each day on the basis of both colostrum and vitamin supplementation. Calves were additionally categorized in a post hoc ANOVA as healthy or ill at the time of each sample per observed scours or fever to quantify the effect of uncontrolled illness on acute phase protein concentrations. Because the overall pattern of SAA expression was different than that of $\mathrm{Hp}$, the effect of nutritional treatment on the difference between $\mathrm{d} 1$ and 7 SAA concentrations was also quantified.

Rectal temperature and dietary milk refusals were grouped into 3 time periods: d 1 to 4 , d 5 to 9 , and d 10 to 13 . Data were analyzed by repeated measures ANOVA by using mixed procedures of SAS. Calf served as the experimental unit; the model included fixed effects of treatment and period and random effect of calf. Contrast statements were used to separate least squares means on the basis of colostrum and vitamin supplementation.

Ordinal data for attitude and fecal scores were analyzed by using a multinomial regression via the GENMOD procedure of SAS. Scores were ordered from least to greatest, with lower scores representing improved attitude or fecal consistency. The model included only the fixed effect of treatment. Contrast statements were used to generate maximum likelihood and odds ratio estimates of the likelihood of a treatment resulting in lower attitude or fecal scores. By default, maximum likelihood estimates were normalized to the performance of the CR-E group.

\section{RESULTS}

\section{Colostrum Replacer and Dietary Milk Analyses}

Haptoglobin, SAA, and $\operatorname{IgG}_{1}$ were quantified in reconstituted colostrum replacer to determine passive introduction to $\mathrm{CR}$ calves. The minimum determined concentration of $\mathrm{IgG}_{1}$ was $393.3 \mathrm{mg} / \mathrm{mL}$, which is above the manufacturer's guaranteed minimum of $375 \mathrm{~g}$ per feeding $(197.4 \mathrm{mg} / \mathrm{mL})$. Concentration of $\mathrm{Hp}$ was 46.8 $\mu \mathrm{g} / \mathrm{mL}$, but quantification of SAA in colostrum replacer was inconclusive. Retinol and $\alpha$-tocopherol were quantified in dietary milk samples and averaged $31.2 \pm$ 2.4 and $4,996 \pm 461 \mathrm{ng} / \mathrm{mL}$, respectively.

\section{Serum $\lg G_{1}$}

To determine effects of colostrum replacer feeding on passive transfer of immunoglobulin to neonates, $\operatorname{IgG}_{1}$ was quantified in serum at $d 1$. Calves supplemented with colostrum replacer at first feeding (all except CD) exhibited greater $(P<0.001)$ concentrations of $\operatorname{IgG}_{1}$ in serum by d 1 of age (Figure 2). Treatment means ranged from 4.07 to $5.94 \mathrm{mg} / \mathrm{mL}$ for calves receiving colostrum replacer, but averaged only $0.11 \pm 0.08 \mathrm{mg} /$ $\mathrm{mL}$ for $\mathrm{CD}$ calves. Concentration of $\mathrm{IgG}_{1}$ in serum at $\mathrm{d}$ 1 was not different among the $5 \mathrm{CR}$ groups, so no effect of vitamin supplementation was observed.

\section{Serum Acute Phase Proteins}

Serum acute phase proteins Hp and SAA were quantified at d $0,1,7$, and 14 to elucidate effects of colostrum replacer feeding and vitamin supplementation on 


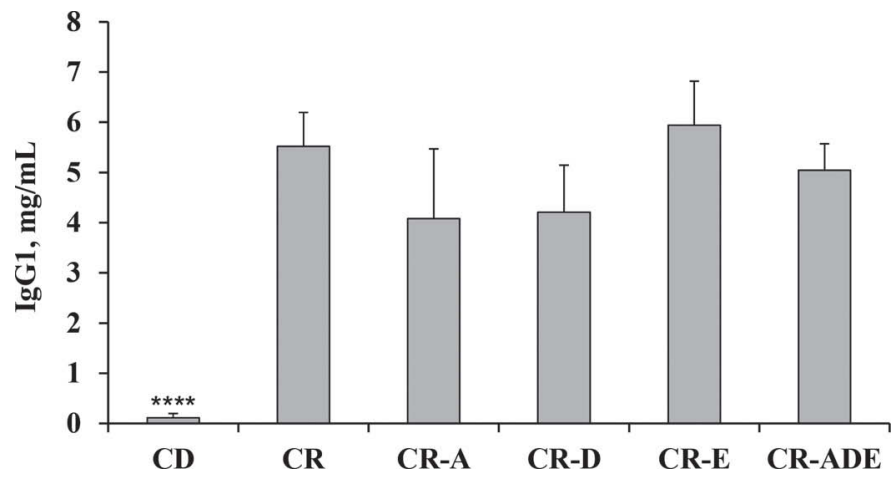

Figure 2. Serum $\operatorname{IgG}_{1}$ at d 1 postpartum. Calves were either colostrum deprived $(\mathrm{CD})$ or fed colostrum replacer alone $(\mathrm{CR})$, or supplemented with vitamin A (CR-A); supplemented with vitamin D (CR-D); supplemented with vitamin E (CR-E); or supplemented with vitamins $\mathrm{A}, \mathrm{D}$, and $\mathrm{E}(\mathrm{CR}-\mathrm{ADE})$. Means \pm SEM. ${ }^{* * * *} P<0.0001 ; \mathrm{CD}$ vs. CR, CR-A, CR-D, CR-E, CR-ADE.

inflammatory responses of the neonate (Table 1). No effect of vitamin supplementation was observed for either protein, but at d 1 , the 5 groups of CR calves exhibited concentrations of serum Hp (Figure 3) and SAA (data not shown) that were $501 \%$ greater $(P<0.01)$ and $96 \%$ greater $(P<0.05)$, respectively, than in $\mathrm{CD}$ calves. Calves were categorized as healthy or ill at the time of each d 7 or d 14 samples in a post hoc ANOVA to determine the effect of uncontrolled illness on acute phase protein concentration. Haptoglobin concentrations in healthy calves averaged $464.6 \pm 227.3 \mu \mathrm{g} / \mathrm{mL}$ and were not different $(P>0.1)$ than that of ill calves, which averaged $874.1 \pm 283.2 \mu \mathrm{g} / \mathrm{mL}$. Significant effects of nutritional treatments within healthy and ill subsets were not observed (data not shown).

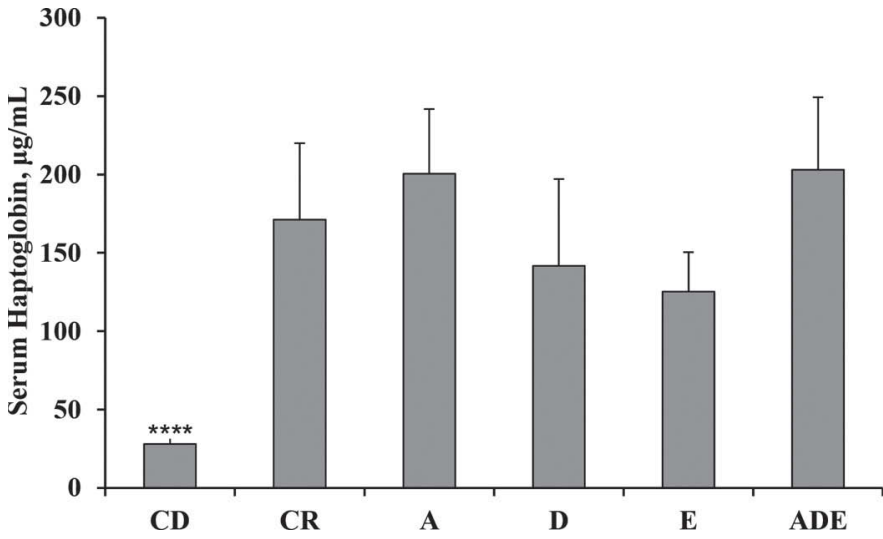

Figure 3. Serum haptoglobin at d 1 postpartum. Calves were either colostrum deprived (CD) or fed colostrum replacer alone (CR), or supplemented with vitamin A (CR-A); supplemented with vitamin D (CR-D); supplemented with vitamin E (CR-E); or supplemented with vitamins $\mathrm{A}, \mathrm{D}$, and $\mathrm{E}$ (CR-ADE). Means \pm SEM. $* * * * P<0.0001 ; \mathrm{CD}$ vs. CR, CR-A, CR-D, CR-E, CR-ADE.

Concentration of SAA was unrelated to clinical health status and averaged $369.3 \pm 54.7$ and $369.8 \pm$ $39.4 \mu \mathrm{g} / \mathrm{mL}$ for healthy and ill calves, respectively. The pattern of expression was different than that of $\mathrm{Hp}$, with peak concentrations occurring at $\mathrm{d} 1$ and 7 . The difference in SAA concentration between d 1 and 7 was quantified for each nutritional treatment and tended to be different $(P<0.1)$ between $\mathrm{CD}$ and combined CR calves; CR calves displayed peak SAA concentration at d $1(297 \mu \mathrm{g} / \mathrm{mL}$, whereas CD calves upregulated the molecule approximately 2.5-fold from d 1 to 7 (212.6 vs. $540.6 \mu \mathrm{g} / \mathrm{mL}$, respectively).

Table 1. Serum haptoglobin (Hp) and serum amyloid A (SAA) concentrations in neonatal dairy calves $(\mu \mathrm{g} / \mathrm{mL})$

\begin{tabular}{|c|c|c|c|c|c|c|c|c|}
\hline Treatment $^{1}$ & \multicolumn{2}{|c|}{$\mathrm{d} 0^{2}$} & \multicolumn{2}{|c|}{ d 1} & \multicolumn{2}{|c|}{ d 7} & \multicolumn{2}{|c|}{ d 14} \\
\hline \multicolumn{9}{|l|}{$\overline{\mathrm{Hp}}$} \\
\hline $\mathrm{CR}$ & 14.7 & 11.3 & 171.1 & 48.8 & 1074.9 & 420.3 & 539.0 & 530.6 \\
\hline CR-A & 40.8 & 30.5 & 200.6 & 41.2 & 475.1 & 453.2 & 73.5 & 71.0 \\
\hline CR-D & 14.4 & 6.9 & 141.8 & 55.4 & 522.9 & 341.2 & 140.3 & 134.7 \\
\hline $\mathrm{CD}$ & 24.8 & 59.0 & $212.6^{*}$ & 58.0 & 540.6 & 155.8 & 561.0 & 307.6 \\
\hline $\mathrm{CR}$ & 201.9 & 84.2 & 448.8 & 116.2 & 587.5 & 140.8 & 253.8 & 103.7 \\
\hline CR-A & 41.7 & 10.5 & 297.4 & 60.6 & 232.4 & 54.9 & 206.8 & 35.4 \\
\hline CR-D & 171.2 & 78.4 & 410.8 & 82.6 & 443.8 & 88.1 & 353.1 & 90.7 \\
\hline CR-E & 71.4 & 39.2 & 370.7 & 85.2 & 374.1 & 131.7 & 189.6 & 0.8 \\
\hline CR-ADE & 172.1 & 97.4 & 556.6 & 94.6 & 653.4 & 126.0 & 495.0 & 163.2 \\
\hline
\end{tabular}

${ }^{1} \mathrm{CD}=$ colostrum deprived, no vitamins; $\mathrm{CR}=$ colostrum replacer, no vitamins; CR-A = colostrum replacer, vitamin $\mathrm{A} ; \mathrm{CR}-\mathrm{D}=$ colostrum replacer, vitamin $\mathrm{D}$; $\mathrm{CR}-\mathrm{E}=$ colostrum replacer, vitamin $\mathrm{E}$; CR-ADE = colostrum replacer, vitamins $\mathrm{A}, \mathrm{D}_{3}$, and $\mathrm{E}$.

${ }^{2}$ Some calves received colostrum before blood collection on $\mathrm{d} 0$.

${ }^{*} P<0.05,{ }^{* *} P<0.01 ;$ CD vs. CR, CR-A, CR-D, CR-E, CR-ADE within day. 


\section{Serum Vitamins}

Retinol, 25-(OH)-vitamin D, and $\alpha$-tocopherol concentrations were measured in serum to quantify the effects of pharmacological vitamin supplementation. Significance of main effects of treatment, day, and the treatment-by-day interaction are stated in Table 2. Calves supplemented with retinyl palmitate (CR$\mathrm{A}$ and CR-ADE) exhibited greater $(P<0.05)$ overall concentrations of retinol in serum compared with nonsupplemented calves (Figure 4A). Retinol in serum did not differ between the CR-A and CR-ADE groups and averaged $279.0 \pm 42.5$ and $230.2 \pm 39.9 \mathrm{ng} / \mathrm{mL}$, respectively, on d 14. Effect of day was evident as calves achieved greater concentrations of retinol in serum by $\mathrm{d}$ 14 than at birth; nonsupplemented and supplemented calves achieved a 2.8 - and 3.0-fold increase, respectively, from d 1 to 14 . Although retinol was not affected by injection of retinyl palmitate at $\mathrm{d} 1$, serum retinyl palmitate was significantly greater $(P<0.001)$ than
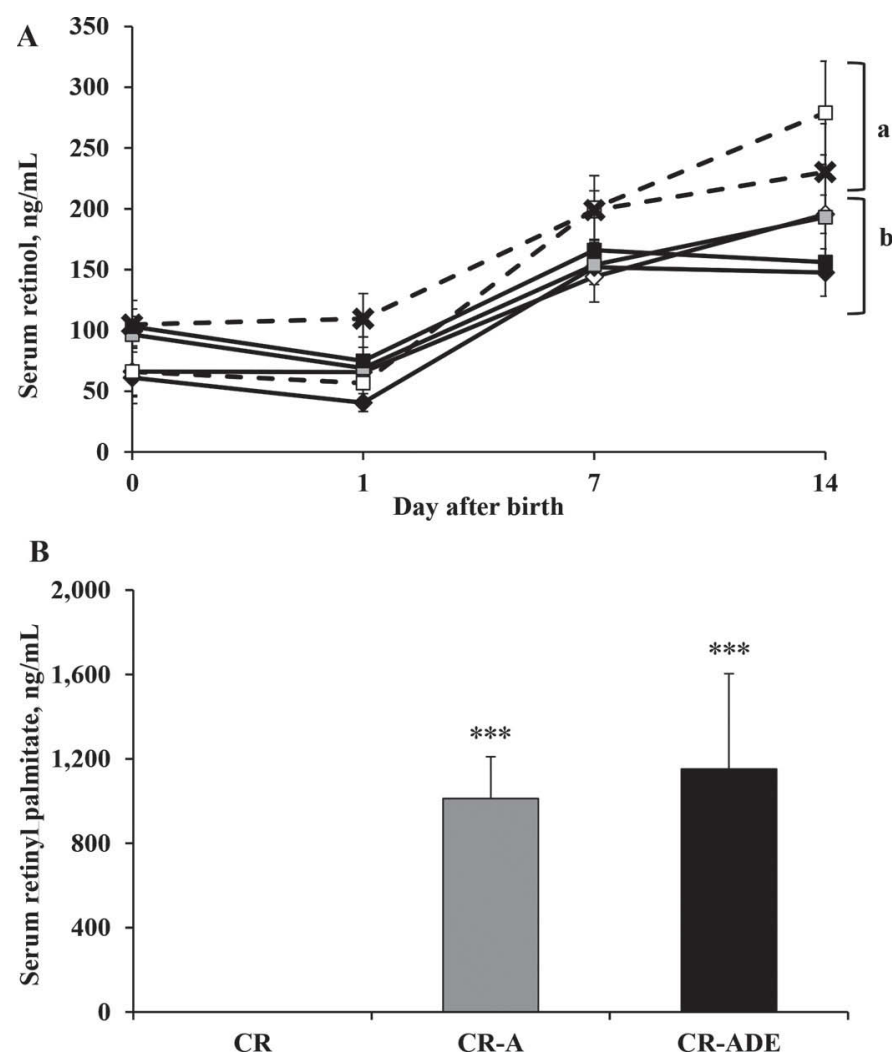

Figure 4. Serum retinol (A) in calves at birth, d 1, d 7, and d 14 of age; and serum retinyl palmitate (B) in calves at $\mathrm{d} 1$. Calves were supplemented with retinyl palmitate via injection at birth and daily oral supplementation of 150,000 and 25,000 IU, respectively (white square, CR-A; black X, CR-ADE), or not supplemented (white diamond, CD, black diamond, CR, gray square, CR-D, black square, CR-E), respectively. Means with different letters $(\mathrm{a}, \mathrm{b})$ are different, $P<0.01$. Means \pm SEM. ${ }^{* * *}$ Denotes difference from $\mathrm{CR}$ control group, $P<0.001$.
Table 2. Effects of treatment and time in data analyzed by repeated measures ANOVA

\begin{tabular}{lccc}
\hline & \multicolumn{3}{c}{$P$-value $^{1}$} \\
\cline { 2 - 4 } Parameter & Treatment & Day & $\begin{array}{c}\text { Treatment } \\
\times \text { day }\end{array}$ \\
\hline Retinol & 0.02 & $<0.0001$ & 0.46 \\
$25-(\mathrm{OH})$-vitamin D & $<0.0001$ & $<0.0001$ & $<0.0001$ \\
$\alpha$-Tocopherol & $<0.0001$ & 0.0005 & 0.003 \\
\hline
\end{tabular}

${ }^{1} P$-value associated with type 3 test of fixed effects in Proc Mixed of SAS (SAS Institute Inc., Cary, NC).

controls in CR-A and CR-ADE calves (Figure 4B), which averaged 1,012 \pm 198 and 1,152 $\pm 452 \mathrm{ng} / \mathrm{mL}$, respectively. Retinyl palmitate was not detected in CR calves and was negligible $(<10.0 \mathrm{ng} / \mathrm{mL})$ in all calves at measured time points other than $\mathrm{d} 1$.

Supplementation of calves with cholecalciferol (CR-D and CR-ADE) resulted in greater $(P<0.001)$ overall concentration of $25-(\mathrm{OH})$-vitamin $\mathrm{D}$ in serum when compared with nonsupplemented calves (Figure 5). No effect of the injection was seen at $d 1$, but by $d 7$ calves in both vitamin $D_{3}$-supplemented groups had greater $(P<0.001)$ serum $25-(\mathrm{OH})$-vitamin D than nonsupplemented calves. Although the concentration of vitamin $\mathrm{D}_{3}$ was the same in CR-D and CR-ADE supplements, the CR-ADE calves had greater $(P<0.05) 25-(\mathrm{OH})$ vitamin $\mathrm{D}$ in serum than did CR-D calves on $\mathrm{d} 7$. By d

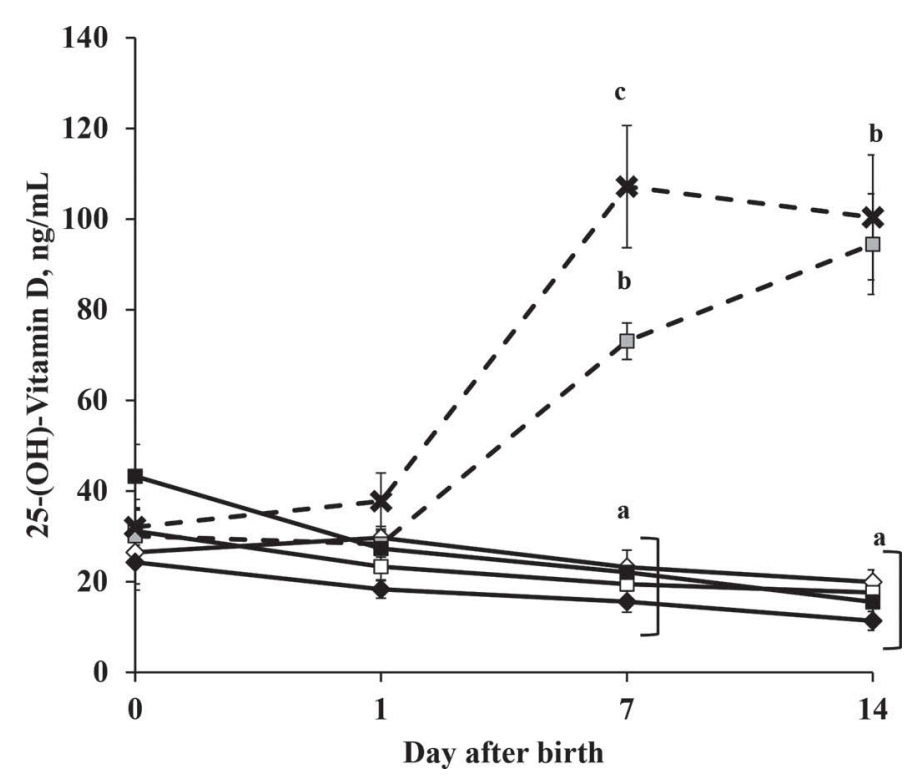

Figure 5. Serum 25-(OH)-vitamin $\mathrm{D}_{3}$ in calves at birth, d 1, 7, and 14 of age. Calves were supplemented with cholecalciferol via injection at birth and daily oral supplementation of 150,000 and 5,000 IU, respectively (gray square, CR-D; black X, CR-ADE), or not supplemented (white diamond, CD, black diamond, CR, white square, CR-A, black square, CR-E). Means \pm SEM. Means with different letters $(\mathrm{a}-\mathrm{c})$ are different, $P<0.001$. 
Table 3. Average milk refusal per feeding (L)

\begin{tabular}{lccccccc}
\hline & \multicolumn{7}{c}{ Treatment $^{1}$} \\
\cline { 2 - 8 } Period & CD & CR & CR-A & CR-D & CR-E & CR-ADE & SEM \\
\hline d 1-4 & 0.018 & 0.048 & 0.227 & 0.213 & 0.002 & 0.041 & 0.092 \\
d 5-9 & $0.429 \dagger$ & 0.073 & 0.036 & 0.094 & 0.000 & 0.315 & 0.158 \\
d 10-13 & 0.131 & 0.000 & 0.224 & 0.352 & 0.264 & 0.266 & 0.206 \\
\hline
\end{tabular}

${ }^{1} \mathrm{CD}=$ colostrum deprived, no vitamins; $\mathrm{CR}=$ colostrum replacer, no vitamins; $\mathrm{CR}-\mathrm{A}=$ colostrum replacer, vitamin $\mathrm{A} ; \mathrm{CR}-\mathrm{D}=$ colostrum replacer, vitamin $\mathrm{D} ; \mathrm{CR}-\mathrm{E}=$ colostrum replacer, vitamin $\mathrm{E}$; $\mathrm{CR}-\mathrm{ADE}=$ colostrum replacer, vitamins $\mathrm{A}, \mathrm{D}_{3}$, and $\mathrm{E}$.

$\dagger P<0.1 ; \mathrm{CD}$ vs. CR, CR-A, CR-D, CR-E, CR-ADE.

14, CR-D and CR-ADE groups averaged 94.5 and 100.4 $\mathrm{ng} / \mathrm{mL}$, respectively. Concentration of $25-(\mathrm{OH})$-vitamin $\mathrm{D}$ in serum of calves not supplemented with vitamin $\mathrm{D}_{3}$ declined below $20.0 \mathrm{ng} / \mathrm{mL}$ by $14 \mathrm{~d}$ of age, which indicated vitamin $\mathrm{D}$ deficiency.

As with vitamins $\mathrm{A}$ and $\mathrm{D}$, calves supplemented with $\mathrm{D}$ - $\alpha$-tocopherol (CR-E and CR-ADE) exhibited greater overall concentrations of $\alpha$-tocopherol in serum $(P<$ 0.001), but a response to supplementation was observed as early as d 1, reaching its highest point during the study (Figure 6). Thereafter, $\alpha$-tocopherol concentrations in vitamin E-supplemented calves approximated $2,800 \pm 600 \mu \mathrm{g} / \mathrm{mL}$, which was significantly greater $(P<0.001)$ than concentrations in nonsupplemented

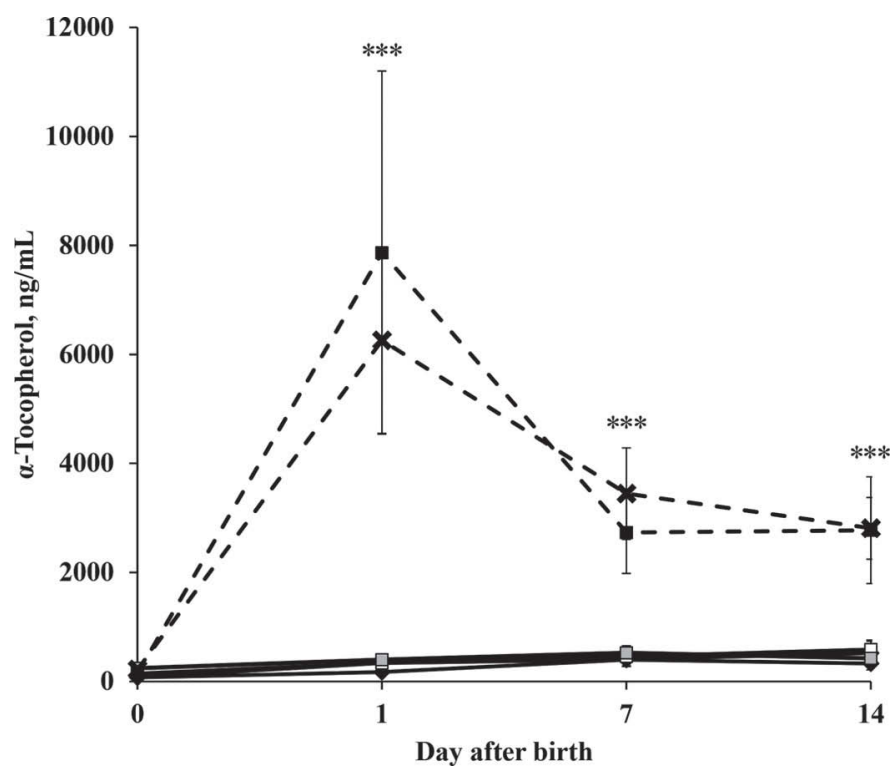

Figure 6. Serum $\alpha$-tocopherol in calves at birth, d 1, 7, and 14 of age. Calves were supplemented with $\mathrm{D}$ - $\alpha$-tocopherol via injection at birth and daily oral supplementation of 1,500 and 500 IU, respectively (black square, CR-E, black X, CR-ADE) or not supplemented (white diamond, $\mathrm{CD}$, black diamond, $\mathrm{CR}$, white square, CR-A, gray square, CR-D). Means \pm SEM. *** Means of supplemented and nonsupplemented groups are different, $P<0.001$. calves. $\alpha$-Tocopherol in serum did not differ between CR-E and CR-ADE groups.

\section{Clinical Health}

Calves were evaluated twice daily to obtain health data; body temperature and volume of refused dietary milk were recorded and calves were scored for attitude and fecal consistency. Mean rectal temperature of calves throughout the study ranged from $38.8^{\circ} \mathrm{C}$ for CR-E calves to $39.0^{\circ} \mathrm{C}$ for CR-ADE calves. Means for these 2 treatment groups tended to be different $(P<$ 0.1 ), but no other differences were detected. Dietary milk refusals are stated in Table 3. Colostrum-deprived calves refused greater volumes of milk $(P<0.1)$ than did CR-fed calves during d 5 to 9 of age. Although not significantly different than other CR-fed calves, CR-E calves refused negligible volumes of dietary milk during the first 2 periods of the trial.

Throughout the study, CR-fed calves were 2.7 times less likely to exhibit signs of depression than were CD calves. Among CR-fed calves, however, those supplemented with vitamin $\mathrm{D}$ were 2.4 times more likely to exhibit depression. Similarly, CR-fed calves were 2.5 times more likely to produce solid feces than were CD calves (Table 4). Among CR-fed calves, however, those supplemented individually with vitamins $\mathrm{D}$ and $\mathrm{E}$ were $2.2(P<0.01)$ and $1.6(P<0.05)$ times, respectively, more likely than others to produce solid feces. The effect was not replicated in CR-ADE calves. Among the fecal samples analyzed for enteric pathogens, $3 \mathrm{CD}$ calves presented with coronavirus, whereas $1 \mathrm{CR}$-control and 1 CR-D calf presented with Cryptosporidium parvum and $1 \mathrm{CR}$-control calf was infected with coronavirus.

\section{MAP Infection Status}

Twenty-two tissues collected from each calf at necropsy were homogenized and cultured on solid medium. Distal jejunum, ileum, and ileo-cecal valve were the primary tissues colonized by MAP in the study. Colony counts were normalized to colony-forming units per 
Table 4. Maximum likelihood estimates of producing lower fecal consistency and attitude scores ${ }^{1}$

\begin{tabular}{|c|c|c|c|c|c|c|}
\hline \multirow[b]{2}{*}{ Category } & \multicolumn{6}{|c|}{ Treatment group ${ }^{2}$} \\
\hline & $\mathrm{CD}$ & $\mathrm{CR}$ & CR-A & CR-D & $\mathrm{CR}-\mathrm{E}^{3}$ & CR-ADE \\
\hline Fecal consistency & -1.31 & -0.82 & -0.68 & 0.27 & 0.00 & -0.65 \\
\hline Attitude & -1.03 & 1.30 & -0.37 & -0.61 & 0.00 & -0.51 \\
\hline
\end{tabular}

gram of tissue and averaged $2.9 \pm 1.2,2.2 \pm 0.9$, and $1.42 \pm 0.4 \mathrm{cfu} / \mathrm{g}$ in culture-positive samples of distal jejunum, ileum, and ileo-cecal valve, respectively. No effects of vitamin treatments on MAP infection of tissue were observed; however, no reportable positive tissues for CD calves were found (Table 5).

\section{DISCUSSION}

Fractionated colostrum replacer fed in this study is a derivative of maternal colostrum; specifically, the colostral fraction that comprises the majority of the dry replacer powder is colostral whey. Thus, this study reveals a previously unrecognized consequence of feeding colostral whey to dairy calves as colostrum replacer. Our principal finding was that calves consuming acellular colostral whey exhibit increased concentrations of $\mathrm{Hp}$ in serum within $24 \mathrm{~h}$ of feeding. The observed increase occurred before inoculation with MAP and, therefore, is not a result of pathogen challenge. HissPesch et al. (2011) demonstrated that both jejunal absorption of $\mathrm{Hp}$ and endogenous hepatic synthesis of the molecule occur within $24 \mathrm{~h}$ postpartum in colostrumfed piglets. Although the present study does not fully

Table 5. Number of calves within treatment group with culturepositive result for Mycobacterium avium ssp. paratuberculosis in select intestinal tissues

\begin{tabular}{lccc}
\hline & \multicolumn{3}{c}{ Tissue } \\
\cline { 2 - 4 } Treatment $^{1}$ & DJ $^{2}$ & Ileum & ICV $^{2}$ \\
\hline CD & 0 & 0 & 0 \\
CR & 1 & 1 & 2 \\
CR-A & 2 & 1 & 2 \\
CR-D & 1 & 1 & 0 \\
CR-E & 1 & 2 & 2 \\
CR-ADE & 2 & 3 & 1 \\
\hline
\end{tabular}

${ }^{1} \mathrm{CD}=$ colostrum deprived, no vitamins; $\mathrm{CR}=$ colostrum replacer, no vitamins; $\mathrm{CR}-\mathrm{A}=$ colostrum replacer, vitamin $\mathrm{A}$; $\mathrm{CR}-\mathrm{D}=$ colostrum replacer, vitamin $\mathrm{D} ; \mathrm{CR}-\mathrm{E}=$ colostrum replacer, vitamin $\mathrm{E}$; $\mathrm{CR}-\mathrm{ADE}$ $=$ colostrum replacer, vitamins $\mathrm{A}, \mathrm{D}_{3}$, and $\mathrm{E}$.

${ }^{2} \mathrm{DJ}=$ distal jejunum; $\mathrm{ICV}=$ ileo-cecal valve demonstrate either mechanism in calves, our finding suggests redundancy across species. Haptoglobin synthesis is induced by IL-6 type cytokines and is thought to attenuate the inflammatory response in a negative feedback loop. Therefore, greater concentrations of $\mathrm{Hp}$ in serum indicate more severe inflammation (Wang et al., 2001; Huntoon et al., 2008). Huntoon et al. (2008) demonstrated aberrant adaptive immune responses in Hp knockout mice, including stunted lymphocyte maturation, disruption of antigen presentation, and failure to mount effective antibody-mediated recall responses.

The role of $\mathrm{Hp}$ in the development of immunity in adult animals suggests that its presence in colostrum also contributes to neonatal immune development that may result in decreased susceptibility to infectious pathogens. The neonatal calf is born without immunoglobulin in a hormonally induced, immunosuppressed state, and innate components of the immune system are complete albeit immature (Chase et al., 2008). Cytokines including TNF- $\alpha$, IL-1 $\beta$, IL-6, IL- $1 \alpha$, and IFN- $\gamma$ in colostrum, and likely in the whey fraction, promote immune system activity, especially monocyte and neutrophil migration to tissues and T helper $2\left(\mathbf{T}_{\mathbf{H}} \mathbf{2}\right)$ biased adaptive responses (Hagiwara et al., 2000; Chase et al., 2008), thus potentiating a requirement for Hp. Because mature B lymphocytes are scarce and respond weakly to $\mathrm{T}_{\mathrm{H}} 2$ signaling (Chase et al., 2008), the $\mathrm{T}_{\mathrm{H}} 2$ bias (and potentially $\mathrm{Hp}$ ) may contribute to establishment of microorganisms throughout the epithelial barrier tissues until a quorum for commensalism is reached. Thus, Hp in colostrum may have an integral role in immune education by supporting the $\mathrm{T}_{\mathrm{H}} 2$ bias.

The $\mathrm{T}_{\mathrm{H}} 2$ bias may partially account for the high infection rate of MAP during the neonatal period, as adult immune responses during the subclinical stage of infection are predominantly $\mathrm{T}_{\mathrm{H}} 1$ mediated (Stabel, 2010). Thus, we hypothesized that an altered inflammatory status of young calves could correlate with severity of early infection. Three tissues (distal jejunum, ileum, and ileo-cecal valve) were identified as primary sites of neonatal infection, but detection of MAP in 
these tissues was sporadic, even among calves of the same treatment. The only difference in inflammatory status was observed at $\mathrm{d} 1$, between $\mathrm{CD}$ and all $\mathrm{CR}$ calves. No difference in acute phase protein expression was observed at d 14 when tissues were collected, and no significant difference in severity of infection in the distal small intestine was observed among treatments. The 3 tissues of interest, however, were negative for MAP in CD calves, thus suggesting that neonatal immune status affects the course of infection. The effects of colostrum deprivation on MAP infection warrant further exploration.

Colostrum-deprived calves also exhibited a lower concentration of SAA at d 1 than did CR calves, but SAA concentration at $\mathrm{d} 1$ was appreciably greater than at d 0. Serum amyloid A was not conclusively quantified in colostrum replacer, but results suggest that the molecule was both transferred passively and synthesized endogenously. Krueger et al. (2014) previously identified increased SAA in calves through the first 3 wk of life that was independent of clinical health, but likely related to early recognition of microbial antigens, as the molecule is associated with high-density lipoprotein mediated clearance of bacterial LPS (Chiba et al., 2011). Quantifiable SAA at d 1 of age in CD calves supports the hypothesis of endogenous SAA synthesis within the first 24 of life. Perhaps SAA was not a critical component of the inflammatory response in the present study because MAP does not have a LPS component.

This study also explored the dynamics of pharmacological vitamin supplementation to the neonatal calf by injection and oral administration. Calves received fractionated colostrum replacer that excluded colostral fat, and thus was assumed void of vitamins $\mathrm{A}, \mathrm{D}_{3}$, and $\mathrm{E}$ per the manufacturer. Calves consuming maternal colostrum have additional basal exposure to fat soluble vitamins, but vitamin status of calves fed maternal colostrum (Krueger et al., 2014) are in agreement with calves of CD and CR control groups in our study, which indicates that colostral vitamins have minimal long-term effect on concentration of vitamins in serum. Injection with D- $\alpha$-tocopherol caused an obvious and immediate increase in serum $\alpha$-tocopherol that was only partially sustained by the oral supplement after $7 \mathrm{~d}$. In contrast, metabolites of injected vitamins $\mathrm{A}$ and $\mathrm{D}_{3}$ were increased only after sustained supplementation. $\mathrm{D}-\alpha$-Tocopherol is the most bioactive and bioavailable tocopherol (Jensen and Lauridsen, 2007). In contrast, retinyl palmitate requires cleavage of the ester to yield retinol, and vitamin $\mathrm{D}_{3}$ is hydroxylated by hepatic 25-hydroxylase to yield $25-(\mathrm{OH})-\mathrm{D}_{3}$ (Horst et al., 2005). Therefore, the time required for metabolism of the injected vitamins $\mathrm{A}$ and $\mathrm{D}_{3}$ may have exceeded the 12 to $24 \mathrm{~h}$ allotted before our first measurement of their metabolites in serum, whereas the $\mathrm{D}-\alpha$-tocopherol measured was the same compound that was supplemented.

After $7 \mathrm{~d}$ of sustained supplementation, we observed an apparent synergism of vitamins $\mathrm{A}, \mathrm{D}_{3}$, and E supplementation on 25- $(\mathrm{OH})$-vitamin D concentrations. Synergy of this nature is previously undescribed, although vitamin $\mathrm{D}_{3}$ has been shown to exacerbate the aberrations to bone and intestinal physiology caused by hypervitaminosis A, characterized as bovine hyena disease (Takaki et al., 1996). Retinoic acid and 1,25-(OH)vitamin $\mathrm{D}_{3}$ are the bioactive forms of retinol and vitamin $D_{3}$, respectively, and the nuclear receptors of these 2 compounds heterodimerize to cooperatively mediate gene expression (Schräder et al., 1993). It is conceivable that increased retinoic acid via supplemental retinyl palmitate could inhibit the 1-hydroxylase to prevent conversion of $25-(\mathrm{OH})-\mathrm{D}_{3}$ to its di-hydroxylated form, thus accounting for the observed synergy.

The oral vitamin supplementation in this study closely mimicked that published by Nonnecke et al. (2010); thus, we expected vitamin concentrations in serum to exceed values reported in that study $(180,65$, and $2,500 \mathrm{ng} / \mathrm{mL}$ of retinol, $25-(\mathrm{OH})$-vitamin $\mathrm{D}_{3}$, and $\mathrm{d}$ - $\alpha$-tocopherol, respectively, in serum by $\mathrm{d} 7$ ) because of the additional injectable vitamin supplementation on d 0 . Values in supplemented calves at d 7 agreed with expectations, with the exception that $25-(\mathrm{OH})$-vitamin $\mathrm{D}$ was increased beyond expectations in the CR-ADE group. Additionally, $\alpha$-tocopherol exceeded 6,000 ng/ $\mathrm{mL}$ within $24 \mathrm{~h}$ before reverting back to an expected value of greater than $2,500 \mathrm{ng} / \mathrm{mL}$ by $\mathrm{d} 7$.

Notably, serum retinol increased in both supplemented and nonsupplemented calves from d 1 to 14. Retinol measured in milk was equivalent to less than $1 \mathrm{IU}$, but contributions from carotenoids were not measured. Nozière et al. (2006) reported that whole milk from cows fed silage may contain up to $0.215 \mu \mathrm{g}$ of vitamin A per $\mathrm{mL}$, mostly from carotenoids. Using this value, our calves may have received up to 1,278 IU of vitamin A from carotenoids daily in dietary PWM. We observed no indication of vitamin A deficiency in nonsupplemented calves. Nonsupplemented calves, however, did exhibit deficiencies in vitamins $\mathrm{D}_{3}$ and $\mathrm{E}$. Control calves failed to achieve $600 \mathrm{ng} / \mathrm{mL}$ of $\alpha$-tocopherol, and had less than $20 \mathrm{ng}$ per $\mathrm{mL}$ of $25-(\mathrm{OH})$-vitamin $\mathrm{D}$ in serum by $\mathrm{d}$ 7. Concentrations of 3,000 and $30 \mathrm{ng} / \mathrm{mL}$, respectively, have been identified as requirements for good health in adult animals (Weiss et al., 1997; NRC, 2001; Nelson et al., 2012).

Our results agree with previously reported concentrations of vitamins $\mathrm{A}, \mathrm{D}$, and $\mathrm{E}$ in nonsupplemented neonatal calves fed PWM (Krueger et al., 2014). Non- 
necke et al. (2014) additionally identified vitamin D and $\mathrm{E}$ utilization during bovine viral diarrhea virus infection in preruminant calves. In the present study, vitamin D- and E-replete calves were least likely to exhibit scours from uncontrolled illness, but correction of $\mathrm{D}$ and $\mathrm{E}$ deficiencies did not alter expression of acute phase proteins at $\mathrm{d} 7$ or 14 . The CR-E calves tended to have decreased body temperatures throughout the study, but our result was inconclusive, and additional work is needed to evaluate vitamin $\mathrm{E}$ as an anti-pyretic agent. The increased likelihood of depression in vitamin $\mathrm{D}_{3}$-supplemented calves is also notable but remains unexplained by classical vitamin D toxicity characterized by hypercalcemia; 6 calves in a study by Sacco et al. (2012) achieved $177.3 \mathrm{ng} / \mathrm{mL}$ without significantly increased serum $\mathrm{Ca}^{2+}$ or body temperature, although 2 of the 6 calves exhibited acutely increased respiration rates and decreased feed intake.

\section{CONCLUSIONS}

Feeding colostrum to calves is essential in order for them to acquire $\mathrm{Hp}$ and $\mathrm{IgG}_{1}$ within $24 \mathrm{~h}$ of birth. Supplementation of vitamins $\mathrm{D}_{3}$ and $\mathrm{E}$ to whole milk diets is needed to correct deficiencies of these nutrients; however, in the present study correction of vitamin D and $\mathrm{E}$ deficiencies did not alter expression of inflammatory acute phase proteins. Neither feeding of colostrum nor vitamin supplementation had an effect on severity of MAP infection in the first $14 \mathrm{~d}$ of life of the neonatal calf, effects that had not been previously explored. In summary, providing colostrum to young calves not only provides passive humoral protection via $\operatorname{IgG}_{1}$, but provides immune regulatory molecules such as $\mathrm{Hp}$ that may shape endogenous immune development and affect susceptibility to infectious microorganisms.

\section{ACKNOWLEDGMENTS}

This study was partially funded by Stuart Products (Bedford, TX). The majority of the funding for this project was provided by the USDA-Agricultural Research Service. The authors thank the following individuals, all from NADC (Ames, IA): Margaret Walker, Randy Hempel, and Derrel Hoy for their help with laboratory assays, and Brian Conrad, Ben Samek, and Hannah Schroeder for their excellent work with the neonatal calves.

\section{REFERENCES}

Chase, C. C., D. J. Hurley, and A. J. Reber. 2008. Neonatal immune development in the calf and its impact on vaccine response. Vet. Clin. N. Am. Food A 24:87-104.
Chiba, T., M. Y. Chang, S. Wang, T. N. Wight, T. S. McMillen, J. F. Oram, T. Vaisar, J. W. Heinecke, F. C. De Beer, M. C. De Beer, and A. Chait. 2011. Serum amyloid A facilitates the binding of high-density lipoprotein from mice injected with lipopolysaccharide to vascular proteoglycans. Arterioscler. Thromb. Vasc. Biol. 31:1326-1332.

Goff, J. P., K. Kimura, and R. L. Horst. 2002. Effect of mastectomy on milk fever, energy, and vitamins $\mathrm{A}, \mathrm{E}$, and $\beta$-carotene status at parturition. J. Dairy Sci. 85:1427-1436.

Hagiwara, K., S. Kataoka, H. Yamanaka, R. Kirisawa, and H. Iwai. 2000. Detection of cytokines in bovine colostrum. Vet. Immunol. Immunopathol. 76:183-190

Hall, J. A., J. R. Grainger, S. P. Spencer, and Y. Belkaid. 2011. The role of retinoic acid in tolerance and immunity. Immunity 35:13-22.

Hiss-Pesch, S., F. Daniel, S. Dunkelberg-Denk, M. Mielenz, and H. Sauerwein. 2011. Transfer of maternal haptoglobin to suckling piglets. Vet. Immunol. Immunopathol. 144:104-110.

Hollis, B. W., J. Q. Kamerud, S. R. Selvaag, J. D. Lorenz, and J. L. Napoli. 1993. Determination of vitamin D status by radioimmunoassay with an 125I-labeled tracer. Clin. Chem. 39:529-533.

Horst, R. L., T. A. Reinhardt, and G. S. Reddy. 2005. Vitamin D metabolism. Pages 13-31 in Vitamin D. D. J. Feldman, F. H. Glorieux, and J. W. Pike, ed. Academic Press, London, UK.

Huntoon, K. M., Y. Wang, C. A. Eppolito, K. W. Barbour, F. G. Berger, P. A. Shrikant, and H. Baumann. 2008. The acute phase protein haptoglobin regulates host immunity. J. Leukoc. Biol. 84:170-181.

Jensen, S. K., and C. Lauridsen. 2007. $\alpha$-Tocopherol stereoisomers. Vitam. Horm. 76:281-308.

Krueger, L. A., D. C. Beitz, K. Onda, M. Osman, M. R. O'Neil, S. Lei, F. H. Wattoo, R. L. Stuart, and B. Nonnecke. 2014. Effects of $\mathrm{D}-\alpha$-tocopherol and dietary energy on growth and health of preruminant dairy calves. J. Dairy Sci. 97:3715-3727.

Leite, F. L., K. D. Stokes, S. Robbe-Austerman, and J. R. Stabel. 2013. Comparison of fecal DNA extraction kits for the detection of Mycobacterium avium ssp. paratuberculosis by polymerase chain reaction. J. Vet. Diagn. Invest. 25:27-34.

Nelson, C. D., T. A. Reinhardt, J. D. Lippolis, R. E. Sacco, and B. J. Nonnecke. 2012. Vitamin D signaling in the bovine immune system: A model for understanding human vitamin D requirements. Nutrients 4:181-196.

Nonnecke, B. J., M. R. Foote, B. L. Miller, D. C. Beitz, and R. L. Horst. 2010. Short communication: Fat-soluble vitamin and mineral status of milk replacer-fed dairy calves: Effect of growth rate during the preruminant period. J. Dairy Sci. 93:2684-2690.

Nonnecke, B. J., J. L. McGill, J. F. Ridpath, R. E. Sacco, J. D. Lippolis, and T. A. Reinhardt. 2014. Acute phase response elicited by experimental bovine diarrhea virus (BVDV) infection is associated with decreased vitamin $\mathrm{D}$ and $\mathrm{E}$ status of vitamin-replete preruminant calves. J. Dairy Sci. 97:5566-5579.

Nonnecke, B. J., W. R. Waters, J. P. Goff, and M. R. Foote. 2012. Adaptive immunity in the colostrum-deprived calf: Response to early vaccination with Mycobacterium bovis strain Bacille Calmette Guerin and ovalbumin. J. Dairy Sci. 95:221-239.

Nozière, P., P. Grolier, D. Durand, A. Ferlay, P. Pradel, and B. Martin. 2006. Variations in carotenoids, fat-soluble micronutrients, and color in cows' plasma and milk following changes in forage and feeding level. J. Dairy Sci. 89:2634-2648.

NRC. 2001. Nutrient Requirements of Dairy Cattle. Natl. Acad. Sci. Washington, DC

Rhinn, M., and P. Dollé. 2012. Retinoic acid signaling during development. Development 139:843-858.

Robison, J. D., G. H. Stott, and S. K. DeNise. 1988. Effects of passive immunity on growth and survival in the dairy heifer. J. Dairy Sci. 71:1283-1287.

Rosales, F. J., S. J. Ritter, R. Zolfaghari, J. E. Smith, and A. C. Ross. 1996. Effects of acute inflammation on plasma retinol, retinolbinding protein, and its mRNA in the liver and kidneys of vitamin A-sufficient rats. J. Lipid Res. 37:962-971.

Sacco, R. E., B. J. Nonnecke, M. V. Palmer, W. R. Waters, J. D. Lippolis, and T. A. Reinhardt. 2012. Differential expression of cyto- 
kines in response to respiratory syncytial virus infection of calves with high or low circulating 25-hydroxyvitamin D3. PLoS ONE 7:e33074.

Schräder, M., I. Bendik, M. Becker-Andre, and C. Carlberg. 1993. Interaction between retinoic acid and vitamin $\mathrm{D}$ signaling pathways. J. Biol. Chem. 268:17830-17836.

Stabel, J. R. 2010. Immunology of paratuberculosis infection and disease. Pages 230-243 in Paratuberculosis: Organism, Disease, Control. M. A. Behr and D. M. Collins, ed. CABI, Wallingford, UK.

Stabel, J. R., L. Bradner, S. Robbe-Austerman, and D. C. Beitz. 2014. Clinical disease and stage of lactation influence shedding of $\mathrm{Myco-}$ bacterium avium subspecies paratuberculosis into milk and colostrum of naturally infected dairy cows. J. Dairy Sci. 97:6296-6304.

Stabel, J. R., W. R. Waters, J. P. Bannantine, and M. V. Palmer. 2013. Disparate host immunity to Mycobacterium avium ssp. paratuberculosis antigens in calves inoculated with $M$. avium ssp. paratuberculosis, M. avium ssp. avium, M. kansasii, and M. bovis. Clin. Vaccine Immunol. 20:848-857.

Stahr, H. M. 1991. Analytical Methods in Toxicology. John Wiley and Sons Inc., New York, NY.
Takaki, H., S. Fukuda, R. Mori, T. Kodaka, R. Sato, and Y. Naito. 1996. Changes in bone metabolism and epiphysial growth plate in bovine Hyena disease induced by administration of vitamin AD3E premix or Vitamin A. J. Vet. Med. Sci. 58:407-412.

Traber, M. G., and J. Atkinson. 2007. Vitamin E, antioxidant and nothing more. Free Radic. Biol. Med. 43:4-15.

Tripathi, V., and B. Vashishtha. 2006. Bioactive compounds of colostrum and its application. Food Rev. Int. 22:225-244.

Wang, Y., E. Kinzie, F. G. Berger, S. K. Lim, and H. Baumann. 2001. Haptoglobin, an inflammation-inducible plasma protein. Redox Rep. 6:379-385.

Weiss, W. P., J. S. Hogan, D. A. Todhunter, and K. L. Smith. 1997. Effect of vitamin E supplementation in diets with a low concentration of selenium on mammary gland health of dairy cows. J. Dairy Sci. 80:1728-1737.

Wood, D. 2013. Don't short calves on vitamins and trace minerals. Vita plus starting strong calf care E-news, December, 2013, Animix, LLC, Juneau, WI. 